\title{
PASSIONS AND EVIL IN KANT'S PHILOSOPHY
}

\author{
MARIA BORGES \\ Universidade Federal de Santa Catarina \\ Departamento de Filosofia \\ mariaborges@yahoo.com
}

\section{Received:I 2.01.2013; Revised:0I.10.20I4; Accepted:04.12.20I4}

\begin{abstract}
In this paper, I aim at relating passions to evil in Kant's philosophy. I begin by explaining the difference between affects and passions in the text Anthropology from a Pragmatic Point of View. Kant claims that both affects and passions are illnesses of the mind, because both affect and passion hinder the sovereignty of reason. I show that passions are worse than affects for the purpose of pure reason. Second, I relate affects and passions to the degrees of the propensity to evil in the Religion. I analyze the idea of an ethical community as a way to overcome the evil, which goes beyond political and anthropological solutions suggested by Kant.
\end{abstract}

Key words: passion, Kant, evil, religion

\section{Fickle and uncontrolled affects}

According to Kant, feelings of pleasure or displeasure caused by an object can be sensible or intellectual. The former are caused by sensation or imagination; the latter are triggered by a concept or idea. (Ant, AA 7:230)․․ Pleasure and displeasure given by sensibility alone are feelings of gratification and pain.

${ }^{1}$ I will use the following abbreviations: G for Groundwork, TL for Doctrine of Virtue, Ant for Anthropology from a Pragmatic Point of View, MS for The

Manuscrito - Rev. Int. Fil., Campinas, v. 37, n.2, pp. 333-355, jul.-dez. 2014. 
Kant defines affects as belonging "to the feeling of pleasure and displeasure", while passions belong "to the faculty of desire." (Lectures on Anthropology, Mrongovius (25,2: 1340). In the Lectures of Metaphysics taught in the 1770's, Kant explains that feeling is related to the way we are affected by an object, rather than to properties of object: "If I speak of an object insofar it is beautiful or ugly, agreeable or disagreeable, then I am acquainted not with the object in itself, as it is, but rather as it affects me."(Metaphysik L1, 28:245)

The difference between the feelings related to affects and the feelings related to the beautiful can be discerned in the Anthropology (Ant, 7:230), where sensuous pleasure is divided into pleasure derived from sensation and pleasure derived from the imagination. While the feeling for the beautiful is partly sensuous, partly intellectual, depending upon the harmony between the cognitive faculties of understanding and imagination, the feeling of pain (Schmers) and gratification (Vergnugen) is related to the pleasure and displeasure of sensation alone.

Affects are feelings of pleasure or displeasure that hinder the reflection through which inclinations were to be submitted to rational maxims; they are sudden and rash, making reflection impossible (TL, 6:408), such as water that breaks through a dam or a stroke of apoplexy (Ant, 7:252). They can lead the agent to moral blindness, since they hinder deliberation, with the consolation that this emotional storm

Metaphysics of Morals, Rel for the Religion within the boundaries of reason, Idee for Idea for an universal history with a cosmopolitan aim. The numbers refer to volume and page (volume: page) of the Academy Edition (Kant's gesammelte Schriften, Königlichen Preußischen (later Deutschen) Akademie der Wissenschaften. Berlin: De Gruyter, 1900 -). I will use the translations of The Cambridge Edition of the Works of Immanuel Kant, Paul Guyer and Allen Wood (editors).

Manuscrito - Rev. Int. Fil., Campinas, v. 37, n.2, pp. 333-355, jul.-dez. 2014. 
easily goes away and calms itself, allowing the subject to go back to a state where reflection is possible again. He cites the example of someone who marries out of love and is blind to the flaws in the character of her beloved, but regains her vision a week after marriage (Ant, 7: 253). The Kantian paradigmatic example of affect is anger, a tempestuous feeling by nature, and fickle like love.

The fickleness of the affect of love can be illustrated in Juliet speech in the Shakespearean tragedy, Romeo and Juliet:

ROMEO ( Act 2, Scene II):

Lady, by yonder blessed moon I vow,

That tips with silver all these fruit-tree tops--

JULIET:

$O$, swear not by the moon, th' inconstant moon,

That monthly changes in her circle orb,

Lest that thy love prove likewise variable.

ROMEO:

What shall I swear by?

(...)

JULIET:

Well, do not swear. Although I joy in thee,

I have no joy of this contract tonight.

It is too rash, too unadvised, too sudden;

Too like the lightning, which doth cease to be

Ere one can say it lightens.

Here one can understand the fickleness of affects: they are too rash, unadvised, too sudden, they go away very quickly. 
While explaining the essence of affects in the Anthropology, Kant refers to the Scottish doctor John Brown:

Affects are generally morbid occurrences (symptoms) and may be divided (according to analogy with Brown's system) into sthenic affects as to strength and asthenic affects as to weakness. Sthenic affects are of the exciting and frequently exhausting nature; asthenic affects are of a sedative nature, which often prepare for relaxation. (Ant, 7:256)

Many eighteenth centuries medical writers had claimed that the causes of diseases are excesses or irregularities in human activity. John Brown (1735-88) towards the end of the century also thought that the same external powers of nature that produce life and health also produces sickness and death. He saw the decline of the organism in quantitative terms, as a loss of excitability, which decreases slowly in quantity everywhere in the body from childhood to old age. Life is nothing but a forced state; if the exciting powers are withdrawn, death necessarily follows. The cause of diseases is an increase or decrease of excitability. Sthenic diseases are caused by an excess of exciting powers, while asthenic diseases by a loss of exciting powers.

Following Brown, Kant talks about affects as physiological states of excitement or release. Laughing with emotion (a sthenic affect) is an example of the first; weeping with emotion (an asthenic affect) is an example of the second. Furthermore, many other affects are related to bodily functions: anger, if one can scold freely, is a way to aid digestion (Ant, 7:261) and fear in battle could be related to acid indigestion. (Ant, 7:256).

\section{Passion and evil maxims}

Kant 's realm of inclinations also includes passion, which is related to the faculty of desire and refers to a strong desire for

Manuscrito - Rev. Int. Fil., Campinas, v. 37, n.2, pp. 333-355, jul.-dez. 2014. 
something. Passion is also related to sensation, however it is not linked to the way we are affected by an object, but to the way we desire it. The faculty of desire admits four levels of intensity: the first is propensity (Hang, propensio), when one have a desire that precedes the representation of the object. In the Lectures on Anthropology/ Mrongovius (AntM, 25,II,1340), Kant mentions the north people's tendency to drink strong drinks as an example of propensity. The second is instinct (Instinkt), which consists in a desire without previously knowing the object by which it is satisfied, e.g., a child's instincts desire for milk or the instinct of an animal to protect his offspring (Ant, 7: 265). The third level is inclination (Neigung, inclinatio) ${ }^{2}$, which is defined as a habitual desire, and exemplified with the desire to play games or drink. If an inclination is too strong, it becomes a passion (Leidenschaft, passio animi), which is the last degree of the faculty of desire. Inclination, Kant argues, is "a habitual sensuous desire", and passion is the "inclination which can hardly, or not at all, be controlled by reason" (Ant 7:251).

In the light of the analysis of passions and affects, could we still agree with the Kantian claim about the reality of practical freedom, as the independence of the will regarding inclinations? Affects and passions are said to be an obstacle to moral deliberation, however he also draws on a strong picture of freedom, which does not allow for pathological compulsion. In the Lectures on Ethics / Mrongovius, we read:

Can I really conceive of a pathological compulsion in man as well? Truly, I cannot, for freedom consists in this, that he can be without compulsion in the pathological sense; nor should he be compelled in

\footnotetext{
${ }^{2}$ Although inclination is sometimes used to refer to all sensible incentives of human nature that is opposed to reason, in its specific definition, it refers to only one of the divisions of the faculty of desire.
}

Manuscrito - Rev. Int. Fil., Campinas, v. 37, n.2, pp. 333-355, jul.-dez. 2014. 
that way. Even if a man is so constrained, he can nevertheless act otherwise. (29:618)

We have strong emotions, difficult to control, but we have means to tame them in order to act the way we want. Virtue is one of these means. We are not responsible for emotions, although we can be held responsible for actions, since the strength of emotions cannot be equated to compulsion, such as the compulsion for drugs. Some philosophers have tried to establish this kind of parallel between strong emotions and addiction. (Elster, 2000). Kant would not accept this picture, because as strong as emotions can be, and as much of a problem for morality that they can portray, the very idea of practical reason presupposes that agents can decide how to act. In fact, the Kantian picture here is more likely to be accepted by moral common sense, since a strong emotion can never be taken as a total excuse for a bad action. Agents can mention strong anger to explain their violent acts, yet not to forgive them. People are held responsible for wrong actions due to strong emotions, because it is presupposed that they could have acted otherwise.

If we disregard, for the moment, the difference in how they are related to objects, we find that both affects and passions are considered illnesses of the mind, because both affect and passion hinder the sovereignty of reason. However, the former is less harmful than the later. This can be shown if one compares anger (affect) with hate (passion). Anger intensifies quickly and subsides in an equally instantaneous manner. Hatred, because it is a passion, does not allow of such control.

Since the passions can be coupled with the calmest reflection, one can easily see that they must neither be rash like the emotions, nor stormy and transitory; instead, they must take roots gradually and even be able to coexist with reason (Ant, 7:266)

Manuscrito - Rev. Int. Fil., Campinas, v. 37, n.2, pp. 333-355, jul.-dez. 2014. 
Passions are more closely related to the will; nevertheless, this does not imply that they can be brought under greater control by reason. They can be considered a perversion of reason, since they "take roots" into reason and coexist with rational decision. Curiously the irrational aspects of affects make it preferable to passions. Kant uses many medical metaphors to stress just this distinction: affect is an intoxicant that causes a headache while passion is a poison that causes a permanent illness (Ant, 7:252), affect is a delirium (7:266) or a "stroke of apoplexy" (7:252), while passion "works like consumption or atrophy" $7: 252)$ or an illness that abhors all medication (7:266), passions are "cancerous sores for pure practical reason " (7:266) to which the physician of the soul could only prescribe palliative medicines $(7: 252)$. The metaphorical bundle of infirmity of emotions speaks to their degree of evil. Affect, the least dangerous of the "illnesses of mind", is related to weakness which can still coexist with a good will:

Affects belong to feeling insofar as, preceding the reflection; it makes this impossible or more difficult. Hence, an affect is called precipitate or rash (animus praeceps), and reason says, through the concept of virtue, that one should get hold of oneself. Yet this weakness is the use of one's understanding coupled with the strength of one's affects, is only a lack of virtue and, as it were, something childish and weak, which can indeed coexist with the best will" (TL, 6:408)

Passions exhibit a contradictory nature. On the one hand, Kant says that they hinder the control of reason to compare at a particular moment, a specific inclination against the sum of all inclinations (Ant, $7: 265)$. On the other hand, they admit some rational deliberation about the means to obtain what the agent desires. One good example is given in the Anthropology, where Kant compares the inability of a man who feels the affect of love to seduce someone, to the skill of one who is taken by the passion of love. The first will not be successful, while the

Manuscrito - Rev. Int. Fil., Campinas, v. 37, n.2, pp. 333-355, jul.-dez. 2014. 
second can easily trap the helpless victim (Ant, 6:265). The difference is that one is immersed in a full agitation of the mind, while the other keeps a cold blood to plot the way to obtain his goal..

While affects are outbursts of feelings, which can coexist with a good, however weak heart, passions are persistent inclination that can lead the agent to choose maxims against the moral law. Here evil does not come from frailty, but from the choosing a maxim against the moral law. This can be illustrated by Lady Macbeth's speech in the play Macbeth, in which she calls the evil spirits to make her follow the wicked maxim she decided for her action.

Lady Macbeth (Act I, Scene V)

Come, you spirits

That tend on mortal thoughts, unsex me here, And fill me from the crown to the toe top-full

Of direst cruelty! make thick my blood;

Stop up the access and passage to remorse,

That no compunctious visitings of nature

Shake my fell purpose, nor keep peace between

The effect and it! Come to my woman's breasts, And take my milk. for gall, you murdering ministers,

Wherever in your sightless substances

You wait on nature's mischief! Come, thick night,

And pall thee in the dunnest smoke of hell,

That my keen knife see not the wound it makes,

Nor heaven peep through the blanket of the dark,

To cry 'Hold, hold!'

Passions does not operate such as affects do. An agent taken by an incontrollable affect may act against the maxim she has decided Manuscrito - Rev. Int. Fil., Campinas, v. 37, n.2, pp. 333-355, jul.-dez. 2014. 
to follow, what may lead to irrational actions, that goes beyond what one call rational agency. On the contrary, passions may form maxims of action, which speaks of their evil disposition. Actions from passions belong to the realm of rational agency; however, they do not follow prudential reasons. This is the case of the ambitious man. If ambition is only an inclination, one can have ambition as grounding maxims of action, which will lead to the conquest of which is desired by the ambitious man. When ambition as passion grounds maxims of action, since passion is a mania $(S u c h t)$, it can lead to the opposite of what is desired. A blind ambition, such as Lady Macbeth's lust for power, can lead to the opposite of what is ambitioned. She madly wanted her husband to be king, but she ended up causing his death.

Passions are beyond the weak adjectives of 'childish', because they are not just signs of weakness, but the true evil:

A passion is a sensible desire that has become a lasting inclination (e.g., hatred, as opposed to anger). The calm with which one gives oneself up to it permits reflection and allows the mind to form principles upon it and so, if inclination lights upon something contrary to the law, to brood upon it, to get it rooted deeply, and so take up what is evil (as something premeditated) into its maxim. And this evil is then properly evil, that is, true vice." (TL, 6:408)

Unlike affects which are temporary emotions, passion is characterized as a lasting inclination. Evil is connected to reflection and to the will's formulation of maxims based on emotions. While an affect constitute a subjective incentive that opposes a maxim, passion may form principles for action. The passion of ambition, for instance, can lead someone to premeditate a murder. One could also murder someone based on a momentary uncontrolled affect. Even if the wrong action is the same, the latter is based on a discrepancy between the force of emotion and the will; the former is based on a will that has

Manuscrito - Rev. Int. Fil., Campinas, v. 37, n.2, pp. 333-355, jul.-dez. 2014. 
chosen to act according to a non-moral maxim. That is the reason why Kant says that passions are worse to freedom than affects:

\begin{abstract}
One can also easily see that passions do the greatest harm to freedom; and if affect is a delirium, then passion is an illness which abhors all medication. Therefore, passion is by far worse than all the transitory affects which stir themselves at least to the good intention of improvement; instead, passion is an enchantment which also rejects improvement" (Ant, AA 7: 266).
\end{abstract}

The evil character of passions comes from two features. First, passion leads the agent to choose immoral maxims, which are decided as such upon reflection. It implies that these maxims present a kind of perversion of moral reasoning, which inverts the priority of the moral maxims and the maxims based on self-love. Second, passions are never completely satisfied, for that reason they are labeled by the word mania $($ Sucht), meaning that they become an obsession about their never conquered object. That is the reason why Kant supports that no physical love can count as passion. Only the refusal of the object of the love can turn the affect of love into a passion of love.

There are also other feelings that can be either an affect or become a passion. Besides love, Kant gives the example of ambition. An ambitious person, besides its own ends, usually wants to be loved by others; however, if he is passionately ambitious, he can be hated by others and even run the risk of becoming poor, because his passion makes him blind. If ambition, however, remains as an inclination, it will be compared to other inclinations and will not ruin the ambitious man. That is the reason why Kant declares that "inclination, which hinders the use of reason to compare, at a particular moment of choice, a specific inclination against the sum of all inclinations, is passion". (Ant, 7: 265).

Manuscrito - Rev. Int. Fil., Campinas, v. 37, n.2, pp. 333-355, jul.-dez. 2014. 


\section{Social Passions}

Kant classifies passion into natural and social ones. Natural passions are called "burning passions", e.g., the inclinations for freedom and sex; the second ones are called cold passions and are ambition (Ehrsucht), lust of power (Herrschsucht) and greed (Habsucht) (Ant, AA 7:272-275). The passion of freedom should not be understood as a rational desire to determine the will in an autonomous way; rather it is a desire not to depend on other people: "whoever is able to be happy only at the option of another person, feels that he is unhappy" (Anth, AA 7:268). It is a natural desire, a desire to keep others far away, and to live "as a wanderer in the wilderness". It is a desire, not to depend on anyone, which belong to the natural man before "public law protects him", i.e., in the state of nature.

However, the most dangerous passions are not the innate, but the acquired ones, which arise from culture. In the Religion, Kant states that the evil principle of human nature belong to passions, "which wreak such great devastation in [human being's] originally good disposition" (Rel, AA 6:93), referring mostly to the social passions of addiction to power, addiction to honor and greed. Their danger consists in their having characteristics of reason: "passion appears to imitate the idea of a faculty which is closely linked with freedom, by which alone those purposes can be attained". (Ant, AA 7:270). Passions imitates rationality in the sense that they can calculate means to desired ends. On can notice this in the analysis of greed. Kant explains this passion as the desire to have all that is good: "money is a password, and all doors, which are closed to the man of lesser means, fly open to those whom Plutus favors". (Ant, 7:274). Although greed is a passion and is not related to the moral self-determination of an agent, it is related to a calculus of the means to have everything materially worthy and to open all doors forbidden to the poor.

Manuscrito - Rev. Int. Fil., Campinas, v. 37, n.2, pp. 333-355, jul.-dez. 2014. 
In the Religion, Kant maintains that inclinations are good and that evil should be searched in a rational principle. In the Anthropology, it is shown that both affects and passions may impede the will, either as a stormy feeling that hinders the accomplishment of the action based on a moral maxim, or by entering in the choice of the maxim. Both in the Religion and in the Anthropology, Kant claims that the worst evil resides in a rational principle, not in a natural one. The evil principle should not be searched in man's raw nature, but in its rational perversion.

The extirpation of affects is not Kant`s necessary purpose and he even claims in that extirpation of inclinations would "not only be futile but harmful and blameworthy as well" (Rel, 6: 58). However, it is an invariable position that we should extirpate passions, since they are not natural feelings or inclinations. That the evil of passions are worse than the evil of affects can be attested by many passages in the Religion. Kant even cites the bible - "we have to wrestle not against flesh and blood (the natural inclinations) but against principalities and powers, against evil spirits" (Rel, AA 6:60) - in order to asseverate that evil does not reside in sensible incentives. Affects can be the cause of weakness, but passions are the cause of true evil.

In his analysis of emotions and evil in Kant, Michael Rolf correctly argues that, for Kant, "all passions are evil, and that all passions are social in content", but Kant "does not claim, and in fact he explicitly denies, that affects are evil, at least in the sense that passions are evil." (Rohlf, 2013, p.755). He considers that "affects, in contrast with passions, are not evil in the way passions are because they lack what makes passions evil, namely, a maxim opposed to the moral law." (Rohlf, 2013, p. 759)

Manuscrito - Rev. Int. Fil., Campinas, v. 37, n.2, pp. 333-355, jul.-dez. 2014. 


\section{The social basis of pure evil}

In order to win the battle against this principle of evil, one should find its cause. If men search the circumstances that lead them to evil principles, they will find out that they are not related to their raw nature, but to the corruption of the will that one man produce over the others. If a man consider himself poor, he does so "only to the extent that he is anxious that the other human beings will consider him poor and will despise him for it”. (Rel, AA 6: 94).

In their works about evil, both Allen Wood (Wood, 2010) and Sharon Anderson- Gold (Anderson- Gold, 2001) call the attention for the fact that evil in Kant has it is source in our social condition. Since evil is originated from social relations, fighting against the evil of passions implies an effort to build a new society that could counteract passions.

In the chapter "Radical evil" of the book Political Emotions, Martha Nussbaum also stresses the social feature of human evil in Kant. She says, "the fact that we are animals is not the primary source of our moral difficulty" and Kant's "key contention is plausible: the tempter, the invisible enemy inside, is something peculiarly human, a propensity to competitive self-love, which manifests itself whenever human beings are in a group". (Nussbaum, 2013, p. 166)

The raw nature of men, although can produce strong inclinations that are difficult to master, does not lead to corruption of the human heart. Kant is unequivocal in asserting that only association of men is able to produce pure evil:

Envy, addiction to power, avarice, and the malignant inclinations associated with these, assail his nature, which on its own is undemanding, as soon as he is among human beings. Nor it is

Manuscrito - Rev. Int. Fil., Campinas, v. 37, n.2, pp. 333-355, jul.-dez. 2014. 
necessary to assume that these are sunk into evil and are examples that lead him astray: it suffices that they are there, that they surround him, and that they will mutually corrupt each other's moral disposition and make one another evil. ( Rel, AA 6: 94)

This claim is unambiguous: the inclinations are not by themselves the source of evil, nor are our affects. The passions of envy, addiction to power and avarice are awaken by the interaction with other human beings, even if there were nothing as a bad behavior from others. Human beings are not evil because they are corrupted by the already wicked persons. The ordinary social interaction make human beings evil, because this interaction awakes the comparison between people. Kant also claims that comparison is the source of this social evil: men feel that they are poor because they compare themselves to others, and the fear to be despised or dominated produces the evil passions of ambition and greed.

Nussbaum agrees with this very pessimistic Kantian viewpoint: "even when people are well fed and housed, and even when they are reasonably secure with respect to other prerequisites of well-being, they still behave badly to one another and violate one's other rights" (Nussbaum 2013, p. 167). Evil is neither a matter of social teaching: "Kant is surely right when he suggests that people require no special social teaching in order to behave badly, and indeed regularly do so despite the best social teaching" (Nussbaum 2013, p. 167).

\section{Is virtue enough to heal evil?}

Could virtue also be considered a cure for evil? If evil comes from the weakness of the will, virtue can help to strength the weak will. Weakness is the first degree of the propensity to evil: it refers to the case in which one has a weak will and is affected by a strong affect, and shortly loses control. However, such lack of control is not, properly

Manuscrito - Rev. Int. Fil., Campinas, v. 37, n.2, pp. 333-355, jul.-dez. 2014. 
speaking, a vice, but a lack of virtue. In the Religion, this loss of control is called frailty (fragilitas) of human nature, and consists in taking the moral law as the objective ground of action, although it lacks sufficient subjective force when compared to inclinations (Rel, 6: 30).

Virtue, as strength, could work as a cure for affects, because these are impermanent outburst of feelings. As Kristi Sweet highlights: "There are numerous ways in which Kant defines virtue, and virtue itself is manifold in its constitution, perhaps first in Kant's understanding of it is that it is strength".( Sweet, 2013, p. 85). As strength, it can work against inclinations and affects that make it difficult to maintain our resolve. Virtue implies the abiding for the principle of moral law, but it also requires fortitude in keeping our decision to follow the moral law.

Could virtue be a cure for the third degree of evil, which is called malignity? Recently some authors have pointed out that virtue can be the cure for all evil. Michael Rohlf states that "in general, virtue is the strength to comply with moral maxims in the face of our propensity to evil, understood as our tendency to prefer the satisfaction of inclinations", and the education for virtue "will promote not only a good heart and the adoption of fundamental moral maxims, which together constitute the intelligible character of virtue, but also the strength of will to comply with those maxims in the face of our propensity to evil “ (Rohlf, 2013, p. 762).

However, since the evil of passions is connected to society, this education for virtue can only fully occur in a society based on the idea of virtue. Only a social remedy can overcome these cancers of pure practical reason.

Manuscrito - Rev. Int. Fil., Campinas, v. 37, n.2, pp. 333-355, jul.-dez. 2014. 
If evil is social, the only way to overcome the evil of passions is through a community based on the ideal of the moral good. Virtue in the sense of an individual strength is insufficient to accomplish this task without setting up a society, which will rule over passions.

\title{
6. The overcoming of evil by an ethical community
}

The social solution to evil is clearly stated in the following quote:

\begin{abstract}
Inasmuch as we can see, therefore, the dominion of the good principle is not otherwise attainable, so far as human beings can work toward it, than through the setting up and the diffusion of a society which reason makes it a task and a duty of the entire human race to establish in full scope. For only in this way we can hope for a victory of the good principle over the evil one. (Rel, 6: 94).
\end{abstract}

This society is not juridical-civil society, but an ethical society, which can coexist with the former. While a juridical-civil, or political society, is the relation of human beings to one another under public juridical laws, an ethical-civil society is one which they are united under the laws of virtue alone, without being coerced. They can coexist and be composed by the same members.

An association of human beings merely under the laws of virtue, ruled by this idea, can be called an ethical and, so far as these laws are public, an ethico- civil (in contrast to a juridico-civil society), or an ethical community. It can exist in the midst of a political community and even be made up of all the members of the latter (indeed, without the foundation of a political community, it could never be brought into existence by human beings).(Rel, AA 6:94)

Kant points to an ethical community, which will be the embodiment of virtue and of moral principle. This is not a political society, since even a perfect civil society will not be able to overcome 
passions and therefore defeat true evil by itself. . In addition, this ethical community is a community of virtue, although not of an individual one, but of a shared virtue. It is -as Kant stresses in the above quotation - "an association under the laws of virtue". This association under the laws of virtue may help fighting social passions, while individual virtue could only control affects.

Kantian makes an analogy of this ethical community with a juridico -civil society. In addition, as well as we can oppose the idea of a state of nature to the civil society, we can oppose an idea of an ethical state of nature to an ethical community.

In a political community, the political citizens are still in the ethical state of nature. The citizens cannot be coerced to enter an ethical state, but they can do it. This decisions rest on the persons will, since the citizen of the political community remains free:

The citizen of the political community therefore remains, so far as the latter's lawgiving authority is concerned, totally free: he may wish to enter with his fellow citizens into an ethical union over and above the political one, or rather remain in a natural state of this sort. (Rel, 6: 96)

\section{The ineffectiveness of political institutions}

Kant claims in the Religion that human beings cannot ground the overcoming of evil only in the development of political institutions. In order to attain their moral destination, they will need to build an ethical community. He seems to have changed his mind about a possible progress in history based on the improving of political institutions. In the Idea for an Universal History, he claims that: "the greatest problem for the human species, to which nature compels him, is the achievement of a civil society universally administering

Manuscrito - Rev. Int. Fil., Campinas, v. 37, n.2, pp. 333-355, jul.-dez. 2014. 
right”.(AA, 8:22) In the Idea, the just civil institutions are considered enough to develop the aim of human nature and to accomplish our moral end.

Paul Guyer remarks that there is already a shift from the text Idea for a Universal History (1784) to the appendix of Perpetual Peace (1795). He argues that in the first, moral change will happen through a natural process, while in the second Kant claims that only the free exercise of human will can lead to the moral destination of man. ( Guyer, 2000, p. 408)

Mutchnik claims that in order to understand Kant conceptual shift one must turn to the Religion (1793), "where the problem of radical evil receives its fullest expression". (Mutchnik, 2009, p. xxvii). He criticizes among others, Allen Wood, who has based his interpretation of evil in Kant only in the Idea: "Interpreters like Allen Wood have found in Idea for a Universal History the key to understanding the social dynamics of the propensity of evil, tracing the roots of Kant's view to his thesis about unsocial sociability".(Mutchnik, 2009, p. 2).

The idea of unsociable sociability plays an important role in the Idea, as an explanation of how can immoral inclinations or passions engender a moral outcome. This unsociable propensity, Kant affirms, “ is this resistance that awakens all the powers of human being, brings him to overcome his propensity to indolence, and, driven by ambition, tyranny, and greed, to obtain for himself a rank among his fellows, whom he cannot stand, but also cannot leave alone. " ( Idee, 8: 20)

Some commentators have found in the idea of unsocial sociability the main social evil. Kristi Sweet remarks that : "those who suggest that there is something in our unsociable nature that promotes evil are right". (Sweet, 2013, p. 87) She goes further and associate this 
social evil with the unsociable sociability of human beings "evil and the principle of self- love in which it is embodied is profoundly anti-social. This is highlighted in the way that unsociable sociability is expressed in one's desire to 'direct everything as to get his own way'. (Sweet, 2013, p. 87).

In The Idea for a universal history with a cosmopolitan aim (1784), the unsociable sociability is an antagonism that will overcome our initial unsociable nature: from a bad origin, we will have a good outcome:

Thus happen the first true steps from crudity toward culture, which really consists in the social worth of the human being; thus all talents come bit by bit to be developed, taste is formed, and even, through progress in enlightenment, a beginning is made toward the foundation of a mode of thought which can with time transform the rude natural predisposition to make moral distinction into determinate practical principles and hence transform a pathologically compelled agreement to form a society finally into a moral whole. (Idee, $8: 20$ )

In the Religion, on the opposite, Kant renounces to the idea of a possible moral outcome from immoral passions. There is no possibility that passions left by themselves will find their way to morality. In the Religion, Kant stresses another kind of evil, very different from the unsociable sociability. It is not this tendency to run away from society in order to be lonely that leads to evil, but the passions that are aroused through the comparison with others.

The Anthropology (1797) presents another way to overcome our evil inclinations by the cultivation of a cultivated society.

The summary of what pragmatic anthropology has to say about the vocation (Bestimmung) of the human being is that he is destined (bestimmt) through his reason to live in a society of human beings, and in this society, through the arts and sciences, to cultivate himself, civilize himself, and moralize himself (Ant, 7: 324).

Manuscrito - Rev. Int. Fil., Campinas, v. 37, n.2, pp. 333-355, jul.-dez. 2014. 
Unlike the radical optimist of the Idea, in the Anthropology, Kant acknowledges that there is evil in men, which "is an inclination to desire actively what is unlawful, although he knows very well that it is unlawful." (Ant, 7: 324). He also recognizes that passions are cancerous sores of reason and do not attribute any good property to them. However, some hopefulness still remains, since passions, even if they are sores for pure practical reasons, they can be overcome by the cultivation of arts and sciences. This socio-cultural development, not of the individual, but of the species as a whole will be able to counterbalance evil and accomplish the natural destiny of species, which is to attain full rationality.

However, neither the radical historical optimism of the Idea, nor the cultural confidence of the Anthropology seemed to be enough to overcome evil. In the Religion there is a new condition of this development, the establishment of an ethical community, which is not guaranteed by the suggested cultivation of human being of the Anthropology, nor by the progress of history and political institutions of the Idea.

A social solution, the ethical community, should supplement a historical and cultural solution to evil, since a civil political society, even the most perfect, will not never attain. Wood explains correctly how a moral community differs from every political community:

Its laws cannot be statuses, derived from an arbitrary human authority, but must instead be purely moral laws, which recommend themselves to each man through his own reason. In addition to this, the very principle of a moral community of men will differ from that of a political one. The legislation of every political or juridical state "proceeds from the principle of limiting the freedom of each to those conditions under which it can be consistent with the freedom for everyone'. (Wood, 1978, p 189)

Manuscrito - Rev. Int. Fil., Campinas, v. 37, n.2, pp. 333-355, jul.-dez. 2014. 
The laws of the political community are always coercive laws and a moral community should promote the moral relations between its members. Good laws can compel men to an outward legality, but not to a real inside moral improvement of their character. Without a moral community, we could have an external conformity to the law, but will never attain the full development of morality.

Allen Wood did not realize that a moral community is only necessary because evil in society is not the unsociable sociability but the pure evil, which will never be healed by the development of political and cultural history. However, he is right in explaining the necessity of a moral community to heal evil, because an outward legality is insufficient to attain the full development of morality.

Only an ethical community can overcome evil, because the roots of evil are social, and belong to passions that are stimulated through social interaction. Political institutions are necessary, but not sufficient conditions, because they can compel man to an external legality, but not to an improvement of their heart.

\section{REFERENCES}

GOLD, A. \& MUCHNIK, P. Kant's anatomy of evil . New York: Cambridge University Press, 2010.

GOLD, A. S. Unnecessary evil. Albany, NY: State University of New York Press, 2001.

ELSTER, J. Strong Feelings: Emotion, Addiction, and Human Behavior (Jean Nicod Lectures), Massachusetts: MIT Press, 2000 .

Manuscrito - Rev. Int. Fil., Campinas, v. 37, n.2, pp. 333-355, jul.-dez. 2014. 
GUYER, P. Kant on Freedom, Law and Hapiness. Cambridge: Cambridge Univerity Press, 2000.

KANT, I. Anthropologie in pragmatischer Hinsicht. Kants gesammelte Schriften (Königlich Preussischen Akademie der Wissenschaften, Berlin: Walter de Gruyter \& Co., 1900.

- Grundlegung zur Metaphysik der Sitten. Kants gesammelte Schriften (Königlich Preussischen Akademie der Wissenschaften, Berlin: Walter de Gruyter \& Co., 1900.

.Idee zu einer allgemeinen Geschichte in weltburgelicher Absicht. Kants gesammelte Schriften (Königlich Preussischen Akademie der Wissenschaften, Berlin: Walter de Gruyter \& Co., 1900.

- Kritik der praktischen Vernunft. Kants gesammelte Schriften (Königlich Preussischen Akademie der Wissenschaften, Berlin: Walter de Gruyter \& Co., 1900.

- Metaphysik der Sitten. Kants gesammelte Schriften (Königlich Preussischen Akademie der Wissenschaften, Berlin: Walter de Gruyter \& Co., 1900.

- Religion innerbalb der Grenzen der blossen Vernunft. Kants gesammelte Schriften (Königlich Preussischen Akademie der Wissenschaften, Berlin: Walter de Gruyter \& Co., 1900.

LOUDEN, R. Kant's impure Ethics. Oxford: Oxford university Prss, 2000.

NUSSBAUM, M. Political emotions. Cambridge: MT: Harvard University Press, 2010.

MUCHNIK, P. Kant theory of evil Maryland: Rowman \&Littlefield Publishers, 2009

ROHLF, M. "Emotion and evil in Kant". The Review of metaphysics, 66 (4), pp 749-73, 2013.

Manuscrito - Rev. Int. Fil., Campinas, v. 37, n.2, pp. 333-355, jul.-dez. 2014. 
SHAKESPEARE, W. The Oxford Shakespeare: The Complete Works by William Shakespeare, Stanley Wells, Gary Taylor and John Jowett (ed.). Oxford. Oxford University Press, 2005.

SWEET, K. Kant on practical life. Cambridge /New York: Cambridge University Press, 2013.

WOOD, A. "The intelligibility of evil", in : Anderson Gold \& Pablo Muchnik Kant's anatomy of evil. New York: Cambridge University Press, 2010. . Kant's Moral Religion. Ithaca \& London: Cornell Univerity, 1978. 